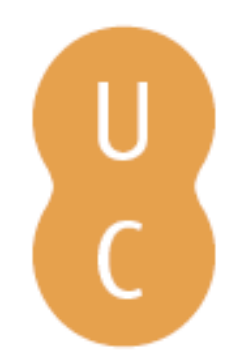

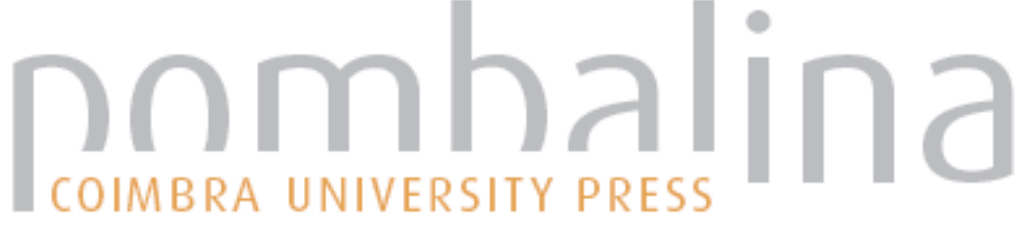

\section{The contribution of genetics to the evolution of evolution}

\author{
Autor(es): $\quad$ Alvarez, Maria Manuela \\ Publicado por: Imprensa da Universidade de Coimbra \\ URL \\ persistente: URI:http://hdl.handle.net/10316.2/31266 \\ DOI: $\quad$ DOI:http://dx.doi.org/10.14195/978-989-26-0342-1_9
}

Accessed : $\quad$ 26-Apr-2023 14:31:04

A navegação consulta e descarregamento dos títulos inseridos nas Bibliotecas Digitais UC Digitalis, UC Pombalina e UC Impactum, pressupõem a aceitação plena e sem reservas dos Termos e Condições de Uso destas Bibliotecas Digitais, disponíveis em https://digitalis.uc.pt/pt-pt/termos.

Conforme exposto nos referidos Termos e Condições de Uso, o descarregamento de títulos de acesso restrito requer uma licença válida de autorização devendo o utilizador aceder ao(s) documento(s) a partir de um endereço de IP da instituição detentora da supramencionada licença.

Ao utilizador é apenas permitido o descarregamento para uso pessoal, pelo que o emprego do(s) título(s) descarregado(s) para outro fim, designadamente comercial, carece de autorização do respetivo autor ou editor da obra.

Na medida em que todas as obras da UC Digitalis se encontram protegidas pelo Código do Direito de Autor e Direitos Conexos e demais legislação aplicável, toda a cópia, parcial ou total, deste documento, nos casos em que é legalmente admitida, deverá conter ou fazer-se acompanhar por este aviso. 
Ana Leonar Pereira João Rui Pita

Pedro Ricarda Fonseca (eds.)
Darwin,

Evalution,

Evolutionisms

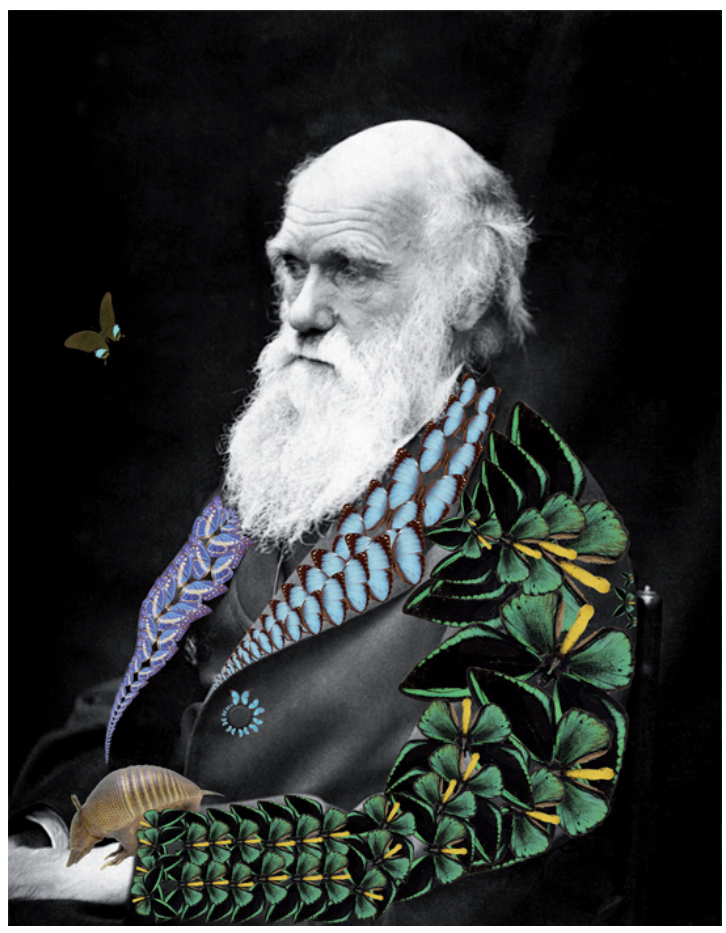


Maria Manuela Alvarez

Departamento de Ciências da Vida, Faculdade de Ciência e Tecnologia, CIAS, Universidade de Coimbra, Portugal

\section{The contribution of Genetics to the evolution of Evolution}

\section{Introduction}

Some 150 years ago, in 1859, Darwin explained why the changes operated in organisms are transmitted from generation to generation, disappearing or becoming more common, depending on their contribution to survival. Later on, between 1936 and 1947, this idea was combined with others, which preceeded from genetics, which was still to be discovered in Darwin's time, and from several others disciplines of Biology. From this combination a new evolutionary paradigm emerged, the Modern Synthesis or the Synthetic Theory of Evolution, which connected inherited genetics and natural selection. According to this conceptual framework the changes operated in organisms are produced by genetic mutations: i) if they contribute to improve organism's fitness they become more common in the population gene pool, and eventually, became part of the species heritage; ii) after gradual accumulation, over successive generations, genetic mutations will originate new species. The Synthetic Theory of Evolution was, and still is, accepted by most biologists and can be considered as a natural update of Darwin's theory as a consequence of subsequent scientific advances i.e. as an evolution of Evolution

The general acceptance of the Modern Synthesis did not prevent the questioning of some of its assumptions. One of them regards the evolution of species over geological time. The evolutionary change by accumulation of genetic mutations proceeds in two levels: within a single species, that contributes to population differentiation over a time scale of generations; and between species, responsible for the onset of new species and other taxonomic groups over geological time. These two scales of evolutionary change are often referred to as microevolution and macroevolution, respectively. While it is often assumed that macroevolution is just an extrapolation of microevolution, the discovery of new phenomena that are not easily explainable within the current paradigm hampers the reconciliation of these two fundamental evolutionary levels.

In the turn of the $20^{\text {th }}$ century, new scientific and technological developments gave a new vision of life, far more complex than that which served as the basis for the Synthetic Theory. In the mid 60s and late 90s genetics experienced two major technological and conceptual revolutions: the molecular revolution, and the "omics" revolution. Both provided new information on organism's variation, and new insights on the forces responsible for their origins. The purpose of this article is to provide a brief recapitulation of genetics' conceptual advances during the $20^{\text {th }}$ century, and the discipline's impact on the history of evolutionary theory. 


\section{"The Eclipse of Darwinism" and the consolidation of the principle of natural selection}

In Darwin's time, the concept of heredity was dominated by two powerful myths. One of them assumed that parental acquired characteristics should be transmitted to the future generations. The other claimed that offspring characteristics were of some intermediate value between those of its two parents, as a result of the mixture of both their blood during the conception - blending inheritance.

In his book entitled The Variation of Animal and Plants under Domestication, published in 1868, Darwin developed a theory of inheritance in which small particles, called "gemmules", were assumed to be shed by the organs of the body and carried in the bloodstream to the reproductive organs where they accumulated in the germ cells. After the union of the two gametes, the gemmules were combined in the zygote so that the offspring would be an analog constructed about the mean of the parental values. This concept of heredity was not compatible with that of natural selection since any advantageous change produced in a singular organism would be diluted in the next generation. "This effect is very similar to that which is obtained when a drop of paint is added to a litre of water: no matter how useful the paint may be in the future, there is no way of recovering the drop" (Dennet, 1995).

At the time Mendel had already demonstrated that the hereditary factors transmitted by both parents to the progeny do not combine, but were passed intact as discrete units. Mendel also proposed rules for the transmission of the hereditary factors, which could be easily observed in the lab through selective cross-breading of chosen lineages. Mendel's experiments were published in 1866 but were largely ignored until 1900, many years after his death.

Mendel's inheritance theory was presented in Great Britain by William Bateson, at a meeting of the Royal Horticultural Society in May of 1900. Classical Darwinists, also known as biometricians, considered Mendel's heredity incompatible with natural selection. They reasoned that if hereditary units passed intact throughout generations as Mendel suggested, they couldn't accumulate changes susceptible to natural selection's scrutiny. Moreover, Mendel's traits were considered largely trivial and non-adaptive. These statements opened a debate between biometricians and Mendelians, originally focused on the clarification of the basis of inheritance. Mendelians were partisans of both models of evolution by natural selection and Mendelian inheritance, however, some of them saw in large effect mutations an opening for the possibility of saltation, the opposite idea of gradual evolution. Darwin was profoundly inspired by the concept of gradualism, and it became the foundation of his theory of evolution. This concept postulated that all geological and evolutionary changes were slow, gradual, and quantitative.

Mendel's work became the foundation of a new discipline in biology, genetics, and its "hereditary factors" were later termed the genes. As it gained recognition and importance in the scientific community, in the 20 years that follow the re-discovery of Mendel genetics, Charles Darwin's conception of evolution by natural selection was considered a theory with a major flaw. He could offer no plausible mechanism to explain the mode of inheritance. During this period, the scientific challenges to Darwinism led many to abandon the theory. Morphologists remained faithful to a morphological ideal, paleontologists tended to be Lamarkists; and all of them agreed 
that evolution progressed in abrupt steps, it was not gradual. Julian Huxley (1942) used the phrase "The Eclipse of Darwinism" to describe this state of affairs.

In 1918 the statistician Ronald Fisher compared the inheritance of traits measurable by real values, with Mendel predictions. He reached a value of significance of 0.99997 , which means that in 100000 simulations only 3 did not fit on Medelian predictions, from which he concluded that the discontinuous nature of Mendelian inheritance was compatible with continuous variation and gradual evolution. Through this statistical demonstration, Fisher reconciled biometricians and Mendelians. However, the experimental proof that Mendelian genes could be mutated was known only in 1927, with the first artificial mutation induction performed by Joseph Muller. By bombing male fruit flies with X-rays, Muller caused the mutation of their genes and noted that the offspring featured new malformations. The idea that the genes were singular molecular entities that could be changed over time provided the experimental support that the theory of natural selection needed to be accepted by the scientific community. Mutation was described as the mechanism responsible for the production of variant forms of a gene, called alleles. This discovery became the foundation of modern genetics.

\section{The birth of Population Genetics and the discovery of a new mechanism of evolution: the random genetic drift}

Through the study of the transmission of heritable traits, the causes of their stability and change, genetics appeared, in the beginning of the 20th Century, as the science that would provide the complete understanding of the evolutionary process. Mendelian genetics originally focused on organism's heredity under controlled experimental conditions, using selected organisms and traits. However, to understand biological evolution, it would be necessary to study the heredity of organisms in the natural environment, where they reproduce randomly within populations. To accomplish this goal Ronald Fisher, Sewall Wright and John Haldane redefined the concept of evolution as the variation of allele frequencies over successive generations. The concept of population was also redefined as a group of interbreeding organisms. Population's properties, such as population subdivision and structure, and effective population size, were tested to estimate their influence on gene frequencies variation, besides natural selection.

Population thinking provided a new scenario for cross-breeding and inheritance. Within populations of limited size parents will produce millions of sperm cells and thousands of eggs cells. From these numerous gametes produced in each generation only a small fraction will be united to form a zygote. The stochastic nature of the gametes sampling process could be responsible for allele's frequency variation. Sewall Wright $(1929,1955)$ demonstrated that if this effect accumulates for several generations, it may cause the fixation or elimination of genetic variant forms, and thus, generate microevolution. The variation of genetic diversity due to stochastic processes became known as "random genetic drift". Its contribution to the origin of species was intensively debated. At the core of the debate was the assumption that natural selection could be excluded from the process. 
Fisher, Wright and Haldane succeed in merging both Darwinian natural selection and Mendelian inheritance theories. The concept of population was central to their approach which became known as "population genetics".

\section{The birth of the Modern Synthesis}

The Theory of Population Genetics was based on sophisticated mathematical models that approximate reality. In this context, "population" was an idealized group of organisms, assumed to be adhering to the assumptions of a theoretical model (e. g. random mating). Those mathematical formulations have kept field naturalists apart from this new approach. Until a second triumvirate, composed by Theodosius Dobzhansky, Gaylord Simpson and Ernst Mayr translated the theory of population genetics into empirical practice. One major achievement of this work was the demonstration that populations had far more genetic variability than the early population geneticists had assumed in their models, and that genetically distinct sub-populations were important reservoirs of variability, which is pivotal to the evolutionary change through time and space.

The conceptual tools supplied by the synthesis between Darwinism and Mendelism proved to be effective in the interpretation of evolutionary change within natural populations. But were they capable of explaining macroevolution? At the time, the criteria to include a singular organism in a particular species was its similarity to a standard form, which was defined by a set of morphological features. Based on this assumption, speciation was described as a process that involved the production of systematic mutations that reorganized the genome, originating singular organisms which deviated, significantly, from the standard form. These organisms, which Goldschmidt (1940) called "hopeful monsters" were the true founders of a new species. The differences between species produced by this mechanism were not of an adaptive nature, and thus, there was no place for natural selection in the speciation process.

Dobzhansky and Huxley suggested that the change in allelic frequencies could lead to the formation of new species if it occurred in isolated populations. This hypothesis was later analysed by Ernst Mayr (1942) leading to a new concept of species, the biological concept as opposed to the typological concept based on morphology. Its main idea was that species are separated from each other by reproductive barriers, which prevent gene flow among their members. In isolated populations the gradual accumulation of genetic variants with slight effect on individual phenotypes, continued for sufficiently long, give rise to reproductive barriers, and thus, to new species or higher taxonomic levels such as genera and families.

During the first part of this century several branches of Biology, such as systematics, morphology, botany, and ecology, incorporated population genetics into evolutionary thinking. From this unanimity a consensus was born about the way how evolution proceeds which was, basically, a Neo-Darwinian theory that recognized the importance of mutation and variation within populations. This synthesis became known as the Synthetic Theory of Evolution or the Modern Synthesis. At its core were three important assumptions. The first assumed that evolution is a process which develops in two phases, in the first, mutations are produced at random; in the second phase, natural selection acts on those mutations as a driving force of evolutionary change 
(in this process the contribution of genetic drift is not significant). The second assumption postulates that evolution is slow and gradual. The third assumed that macroevolution is an extension of microevolution; e. g. the gradual accumulation of genetic variants with slight effect, continued for sufficiently long, gives rise to new species.

For some evolutionists the Modern Synthesis was a major paradigm shift. Karl Popper claimed that the Modern Synthesis is a theory about how evolution works at the level of genes whereas Darwinism was focused mainly on the evolution of form of the organisms and species (Platnick and Rosen, 1987). It is a common thought that developmental biology is missing from the theory of evolution even after the onset of the evolution of development (evo-devo) research program in 2003 (Pigliucci, 2007).

\section{The challenges of molecular evolution}

In 1952 the complete sequence of the protein insulin became known. By the mid-50 's, a considerable amount of data regarding other proteins was available allowing its comparison between species. The amino acid sequences were aligned providing a new scenario of variation between species. Surprisingly, changes did not happen randomly but in particular regions of the molecule - amino acid substitutions in insulin from cows, sheep, pigs, horses and whales, for example, were restricted to positions 8 to 10 of the sequence. Most of these changes did not affect its functional role; and the mutation rate was similar in different species. Based on these data Zuckerland and Pauling (1965) suggested a molecular clock for evolution at the molecular level. This hypothesis was the opposite of erratic tempo of evolution that was assumed at the morphological level. Later on, the molecular clock was used by Sarich and Wilson (1967) to measure the divergence time between humans and chimpanzees in 5 million years. This value was much lower than the 25 millions considered previously.

In 1969, Kimura suggested that a constant rate of evolution most likely was not driven by natural selection. Alternatively he hypothesized that most molecular changes were caused by random drift of neutral or nearly neutral mutations. This same hypothesis was suggested, independently, by King and Juckes (1969) and became known as the Neutral Theory of Molecular Evolution. The term "neutral" used in this context means that the future of different variants of a gene is determined, mainly, by genetic drift. In other words, Kimura's theory suggests that most genetic diversity exists because it does not affect an organism's survival, and not because it was chosen by natural selection.

The neutral evolution model became the foundation of several mathematical models designed to predate divergence times between orthologous amino acid sequences.

The advent of several DNA techniques such as polymerase chain reaction, and direct sequencing analysis has brought a better understanding of gene structure and function. In the late 90's the development of new algorithms for genome analysis, high speed-computers and bioinformatics have enabled fast and reliable predictions regarding evolution, physiology and fitness of the sequenced organisms. Genomic data revealed that genes evolve by duplication and that those which encode proteins are frequently conserved by tens and hundreds of millions of years, exceeding the duration of many species. Genes are now considered as an independent level of evolution, with a deep history, often different from that of the species to which they belong. 
Previously, genes were considered adaptive characteristics of species, not a level of evolution. Furthermore, genomes are no longer described as well-organized libraries of genes, but complex units of information that change rapidly over time due to selection mechanisms operating at multiple levels simultaneously, as well as genetic processes of duplication, transposition, mutation, and recombination.

The new information provided by the molecular and genome studies will force biologists to connect evolutionary and molecular biology. For some of them claimed that the Modern Synthesis needs to incorporate this recent knowledge in a new expanded post-modern synthesis. However, some of its historical defenders argue that the new concepts and empirical findings of the last 20 years are implicit in the theory and, thus, any expansion of its conceptual foundations or grafting of new ideas is dispensable.

\section{Bibliography}

CAVALLI-SFORZA LL, BODMER WF 1999. The Genetics of Human Populations. Dover Publications, Inc. New York.

DENNET DC 1995. Darwin's Dangerous Idea. Touchstone. New York.

GOULD SJ 2000. O Polegar do Panda. Gradiva. Lisbon.

GOULD SJ 2002. Macroevolution. In Encyclopedia of Evolution. Ed.

HARTL D, CLARK A. 1997. Principals of Population Genetics. Sinauer Associates. Sunderland (MA).

HULL DL 2002. History of Evolutionary Thought. In Encyclopedia of Evolution. Ed. Mark Pagel. Oxford University Press, Inc. New York.

HUXLEY J 1942. Evolution: the modern synthesis. Allen and Unwin, London.

JOBLING MA, HURLES ME, TYLER-SMITH C 2004. Human Evolutionary Genetics, Origins, Peoples \& Disease. Garland Science, New Deli.

MAYR E 2001. What Evolution Is. Basic Books, New York.

PAGE RDM, HOLMES EC. 1998. Molecular Evolution: a phylogenetic approach. Blackwell Science, Ltd. London.

PIGLIUCCI M 2004. Do we need an extended evolutionary synthesis? Evolution 61-12: 2743-2749.

PLATNICK NI, ROSEN DE 1987. Popper and evolutionary novelties. History Philos Life Sciences 9: 5-16.

RIDLEY M 2004. Evolution. Blackwell Science, Ltd. London.

ROSE MR, OAKLEY TH 2007. The new biology: beyond the Modern Synthesis. Biology Direct 2: 30 doi: $10.1186 / 1745-6150-2-30$.

WRIGHT S 1955. Classification of the factors of evolution. Cold Spring Harb Symp Quant Biol 20: 16-24. doi:10.1101/SQB.1955.020.01.004 